\title{
PACIFICATION AND INDIGENOUS STRUGGLES IN CANADA
}

\author{
TIA DAFNOS \\ Department of Sociology, York University ${ }^{1}$
}

\begin{abstract}
Front-line police operations are deeply entwined with less visible activities - or practices not commonly identified as policing - that are carried out by a wide range of participants as strategies of settler-colonial pacification operating through the organizing logics of security and liberal legalism. Using open source texts and records obtained through access to information requests, this article unmaps some of the contemporary strategies employed by Canadian institutions to pacify Indigenous resistance. As a contribution to the body of work seeking to develop the politics of anti-security, the analysis disrupts the binary categories that animate security logic by examining the public order policing approach of the Ontario Provincial Police, the framing of Indigenous resistance as a security threat, and the integral role of Indian Affairs in securing the settler-state. ${ }^{2}$
\end{abstract}

\section{Keywords}

colonialism, pacification, Indigenous, resistance, police

Since December 2012, Indigenous peoples and their non-indigenous supporters have engaged in a wide range of direct actions such as round dance flash mobs, blockades of rail-lines, highways and bridges, hunger strikes and demonstrations. These actions, affiliated with the Idle No More movement and reflecting varying degrees of militancy, have been on-going throughout what is now known as Canada, and solidarity actions have occurred around the world. Thus far Canadian police forces largely appear to be following a public order policing approach emphasizing flexibility and communication with protesters. Under this model, police discretionary power is exercised to allow protests to occur while maintaining the safety and "security" of all involved by minimizing physical violence. This approach is often described as "soft" policing in

\footnotetext{
1 Tia Dafnos is a PhD candidate in Sociology at York University. Her dissertation research engages in an (un)mapping of the police-security apparatus involved in responding to Indigenous peoples' protests in Canada. She can be contacted at tdafnos@yorku.ca.

${ }^{2}$ My thanks to the two anonymous reviewers, Elaine Coburn, Mark Neocleous and George Rigakos for their constructive comments on earlier versions of this paper.
} 
contradistinction to "hard" policing characterized by immediate enforcement through coercive force. Yet as Neocleous and Rigakos (2011) argue, this distinction between "soft" and "hard" policing is one of the false binaries at the root of security logics that (re)produce, in this case, the Canadian settler state. Front-line police operations are deeply entwined with less visible activities - or practices not commonly identified as policing - that are carried out by a wide range of participants as strategies of settlercolonial pacification operating through the organizing logic of security and liberal legalism.

My approach in this paper is to turn the research gaze onto state institutions and dominant discourses to unmap colonial strategies (Razack 2002) deployed by the state and settlers in pacifying Indigenous resistance. As a settler, I realize that the role of nonIndigenous scholars as 'experts' presents risks of drowning out Indigenous voices as experts on their own experiences, both of colonialism and of resistance. I have attempted to address this by focusing my analysis on settler colonial strategies more than speaking or commenting on Indigenous resistance.

Drawing on open source texts and on records obtained through access to information requests, my focus is on public order policing, "securitization" and the framing of Indigenous resistance as national security threats to the state and private sector interests, and the policing role of Indian Affairs in securing the settler-state. My analysis seeks to disrupt some of the binary categories that animate the entwined logics of security and liberal legalism that legitimize these practices. The organizing of the world into dichotomous categories, as Monture-Angus (1999, 42) notes, is "a colonial manifestation." Neocleous and Rigakos (2011) argue that disrupting security logic is crucial to counter its de-historicizing and de-politicizing effects. As settlers and as academics, this is a refusal to be complicit in the exercise of colonial power by inhabiting and legitimizing its categories.

\section{Policing, Security and Liberal Legalism}

Drawing on the work of Foucault (2007), Neocleous (2000) and Rigakos et al. (2009), policing is understood as the production or "fabrication" of social order that is amenable to processes of capitalist accumulation. Police power is exercised through a range of techniques and institutions. The police - as a specific institution - is a significant state agent of policing, distinguished by its capacity to use "legitimate" violence to produce this social order. Security is a mode of policing that is historically-specific to the development of capitalism, and organizes society through the politics of liberalism and its technologies of individualism and responsibilization. Liberty, defined in large part by individual accumulation, consumption and possession, is secured through policing; conversely, policing is legitimized by the necessity or demand for liberty (Neocleous 
2008). As Neocleous (2011) argues, this organizing logic of security-liberty should be understood as pacification - the production of social relations and institutions in place of existing forms of social organization. More specifically, it is the fabrication of a "new" society through the destruction of an existing one.

Pacification has an historical-materialist basis in imperialism and colonialism whereby imperial powers attempt to transform societies in ways that facilitate the territorial expansion necessary to the accumulation of capital (see Alfred 2005; Neocleous $2010,2011)$. In the context of settler colonialism, pacification attempts to eradicate existing Indigenous societies while establishing a new society on expropriated land that also erases its colonial past (see Wolfe 2006; Veracini 2010). As Wolfe (2006) emphasizes, settler colonialism is not about replacing, or substituting, a society but the construction of a new one. Pacification thus involves both destructive and productive policing practices, which encompass a wide range of strategies deploying sovereign (repressive), disciplinary and governmental modalities of power simultaneously. The specific permutation of these modalities is dynamic and dependent on context; however, overtly coercive strategies while always present - tend to take a backseat to political and ideological techniques of pacification, specifically those of liberalism. As Manuel and Posluns (1974) argue, "the common good" is an important discursive device in legitimating and securing colonial social order (see also Alfred and Corntassel 2005).

The legal apparatus is therefore a central means of pacification (Neocleous 2010, 2011). Yet it is the omnipresence of state violence that enables disciplinary and governmental techniques (see Alfred 2005). This is evident in the specific legal strategies deployed in fabricating settler colonial order such as the expropriation of land and resources, the displacement and confinement of Indigenous peoples, the criminalization of means of subsistence outside of waged labour, and assimilationist mechanisms such as residential schools and the outlawing of cultural practices. These strategies work to disrupt and destroy Indigenous identities and social, political and economic relations while establishing an order facilitating capitalist accumulation (Monture-Angus 1999; Alfred 2005; Alfred and Corntassel 2005; Coulthard 2007). At the same time, these policing techniques are continuous with those that fabricate class structure through the protection of private property, the ordering of spaces, moral regulation and the criminalization of alternatives to the wage labour market.

There is a dialectical relationship between pacification and resistance, as other contributions in this issue also show, and this relationship sustains a permanent social insecurity inherent to capitalism and the settler state. Thus, pacification is on-going and constantly shifting, shaped by forms of resistance and broader historical-spatial dynamics (see Alfred and Corntassel 2005). Settler colonialism must be understood as a continuing process of constituting society rather than as a temporally-bounded "event" of the past that the "new" society has moved beyond (Wolfe 2006). Anti-colonial and class struggles 
are enduring features of settler colonial states and as Simpson (2008, 13) states, "Indigenous Peoples whose lands are occupied by the Canadian state are currently engaged in the longest running resistance movement in Canadian history," predating the state itself. Pacification projects are on-going "wars" against resistance in the fabrication of order (Rigakos 2011). Using settler-colonial pacification as a conceptual framework, I examine some key facets of the contemporary policing of Indigenous resistance in Canada, which operate with/in security-liberal logic; these policing practices should be understood as continuities of settler-colonialism shaping colonial and class relations. This requires sketching out the interconnectedness of state institutions, which are woven together by the logic of security-liberalism to operate as means of settler colonial pacification vis-à-vis Indigenous peoples and nations.

Comaroff and Comaroff $(2007,144)$ describe the use of law as a means of "political coercion, even erasure" in the colonial context as lawfare. This conception captures the simultaneously destructive and constitutive power of law in settlercolonialism. The contemporary Canadian legal apparatus is organized in and through the framework of liberal legalism, which is symbolized by the constitutional enshrining of individual rights. Canada's inclusion of a Charter of Rights and Freedoms in its 1982 constitution marks its status as a liberal democratic nation-state within the global order, engaged in practices favourable to investment and accumulation (see Goodale 2005). Drawing on the arguments of Brown (1995) and Ford (2002), liberal legalistic "rights" establish norms for behaviour that produce "good" liberal subjects by shaping conduct to be consistent with security logic. In critiquing the politics of recognition, Coulthard (2007) argues that the dominant liberal rights-based discourse, in which these politics are based, constitutes Indigenous peoples as "subjects of empire." This regime of legal liberalism is a central mechanism through which threats to settler state sovereignty and capitalist accumulation are managed.

Thus, within a "liberal democratic" society, "legitimate" means of engaging in political contention include the electoral process, judicial mechanisms to enforce the rule of law and uphold rights, and participating in acts of political dissent in public spaces. The latter instance brings participants into contact with the police institution. Here lies the paradox for Indigenous struggles. The liberal democratic political, legal, judicial, and police institutions are the colonial institutions of the settler state whose legitimacy is being challenged and whose existence is predicated on the elimination of Indigenous societies. Indigenous scholars such as Monture-Angus (1999), Henderson (2002), Alfred (2005), Coulthard (2007), and Corntassel (2008), have emphasized that the arena of liberal rights-based discourse works to limit self-determination in ways that reproduce and reinforce these colonial institutions.

Reflecting the dialectical nature of resistance and pacification, it could be said that gains (although not without significant limitations) have been made in the arena of lawfare, such as the constitutional recognition of Aboriginal and treaty rights and the 
resolution of some land claims. For example, the removal of Indian Act prohibitions on political activities in the $1960 \mathrm{~s}$ facilitated mobilizations relating to the Canadian constitution. In turn, the formal protection of Aboriginal and treaty rights in section 35 has provided a basis for legal challenges to violations and encroachments. Similarly, the lifting of restrictions on use of government money to research land claims is crucial for being able to bring these claims forward. However, these legal processes are always limited by their contradictions or "logical consistencies" (Alfred and Corntassel 2005, 612). The specific claims process established in 1973 is a prime example of this contradiction as the state - through Indian and Northern Affairs Canada (INAC) - plays a dual role as both negotiator for and defendant against Indigenous challenges. ${ }^{3}$ Between 1970 and 2006, only 275 specific claims had been completed of the 1337 filed. With an average of 20 years to settle a claim, communities and land are vulnerable to further encroachments as the claim moves through the process (Gordon 2010; Pasternak, Collis and Dafnos 2013).

Moreover, the constitutional protection of Aboriginal and treaty rights has been compromised through law itself. Although the 1997 Delgamuukw decision affirmed that section 35 protected Aboriginal title the court ruled that the guarantee of exclusive use and occupation of land could be infringed by the Crown based on "valid" objectives. As Henderson $(2002,37)$ states, "[b]y their interpretations of the constitutional order and of our treaty order, the courts created the colonial structure of federal Indian law." Aboriginal and treaty rights have been further targeted through the comprehensive claims process, a form of "modern treaty-making", which is based on extinguishing Aboriginal title (see Monture-Angus 1999; Henderson 2002; Alfred 2005; Coulthard 2007; Gordon 2010). As Coulthard (2007) argues, rights are "recognized" by the state (and settlers) as long as they do not disrupt political-economic relations. Most recently, these constitutional protections have been further eroded through the Conservative government's unilateral adoption of omnibus Bill C-45, which included legislative amendments impacting Indigenous self-determination (see Diabo 2012). Diabo (2012) describes these as part of a "termination plan" enacted by the Harper government, which follows a legacy of political-legal attempts to destroy Indigenous communities through assimilation.

In the context of these colonial political and legal mechanisms, direct action such as blockades and reclamations are often options of last resort, particularly when communities are faced with the imminent loss or desecration of land and rights (Alfred 2005; Borrows 2006; Maaka and Fleras 2005). Such actions are spaces of direct interaction with the police institution, which has been central to the displacement, dispossession and repression of Indigenous peoples in the colonial project (Samuelson and Monture 2008;

\footnotetext{
${ }^{3}$ In June 2011, INAC changed its name to Aboriginal Affairs and Northern Development Canada. As most of my sources precede the name change, and for the sake of continuity, I use INAC throughout this paper.
} 
Gordon 2006, 2010). The liberal legalism of lawfare further extends to this arena of resistance in the state's management of protests and the legitimization of coercive policing that bears a closer resemblance to warfare.

\section{Pacification Through Protest Policing}

In the context of the emergence of liberal legalism in the late twentieth century, Canadian police forces began instituting formal policies and guidelines reflecting the adoption of a "measured response" or negotiation-based approach to public order policing. Following trends in most Anglo-American and western European nation-states, this "new" policing model emphasizes communication and negotiation with protesters, with the purported aim of averting an escalation of physical violence. Explicitly working through liberal legalistic discourse, the aim of this "new" policing is to balance the rights of protesters with ensuring public safety (McPhail, Schweingruber and McCarthy 1998; McPhail and McCarthy 2005). The exercise of dissent in this context is shaped by the responsibilization of subjects to police themselves and others according to the bounds of "acceptable" (that is, legal) behaviour as agreed upon in negotiation with the police.

This "new" approach is often juxtaposed - by police as well as in academic literature - to an "escalated force" approach characterized by coercive policing and disregard for civil rights. In Canada, the "shift" in public order policing has been particularly associated with the policing of Indigenous peoples' protests, blockades and reclamations. This "shift" has therefore been framed by police forces as consistent with, or emblematic of, a more "progressive" policing that is conscious and respectful of rights and of the unique context of the protests. The juxtaposing of these two official policing models positions current practices as desirable according to liberal democratic ideals; the effect, however, is to mask the enduring coercive power underlying these techniques.

Paralleling the imbalance of "negotiation" found in the land claims process, police forces play a dual role in "facilitating" protests while serving as agents of the state with a primary concern to keep the "peace" of settler-colonial order. The notion of a "negotiation" is grounded in the liberal legalistic conception of contractual agreement between autonomous parties, with the inference that the participants have an equal amount of influence and power in shaping the outcome. However, the police institution, being invested with the state's monopoly of use of violence, maintains significant leverage in "negotiations" around the conditions and parameters of protest; the spectre of coercive force is ever-present, whether overt or not. The "flexibility" of this policing approach is an enhancement of discretionary power in the application and enforcement of law.

The exercise of police discretion is informed by, and shapes, distinctions between "good" and "bad" protesters (Waddington 1998; King and Waddington 2006), which reproduces a binary of the good liberal subject and the "uncivilized" Other - a 
fundamental feature of imperialism and colonial control (see LaRocque 2010). Those who do not actively cooperate with police direction, and who engage in disruptive direct actions, would fall into the latter category. The justification for use of overtly coercive or "hard" policing tactics is legitimized by the unreasonableness and irresponsibility of individuals who do not exercise their rights "properly" through "neutral" and "objective" (that is, liberal) legal and political processes or institutionalized forms of protest. Racialization and racist discourse furthers the othering of Indigenous peoples engaged in disruptive direct actions as the "uncivilized" Other - the "internal dangerous foreigner" in the settler colonial state (Dhamoon and Abu-Laban 2009). The logic of securityliberalism neutralizes the threat of resistance by attempting to institutionalize it within "legitimate" liberal democratic channels while also providing legitimization for the state's use of overt and covert repression to manage potential threats to "public safety" - i.e. security - posed by those who have not been or cannot be pacified as good liberal subjects - or "subjects of empire" (Coulthard 2007).

It is significant therefore that implementation of "negotiation"-based policing policies has occurred along with the enhancement of coercive capacities, evident in the normalized use of paramilitary tactical units (such as Emergency Response Teams or tactical teams), joint-training between law enforcement agencies and armed forces units, the proliferation of "less-than-lethal" weaponry, the adoption of command and control structures, as well as the prioritization of intelligence-led policing practices and surveillance. To distinguish these capacities - and their augmentation - as somehow discrete from the adoption of measured response/negotiation based policing is to reproduce a liberal and artificial distinction. Rather than oppositional or contradictory, these strategies reflect an intensification of the politics and techniques of security and liberal legalism.

To illustrate the institutionalization of these policing strategies, the Ontario Provincial Police (OPP) serves as a clear example. The shooting of Anthony "Dudley" George by the OPP during the 1995 Ipperwash reclamation was a significant catalyst in the formalization of a negotiation-based public order policing approach by the organization. The OPP's reforms in this respect were built upon three pillars: a plan for developing better relationships between the force and Indigenous communities, the introduction of Aboriginal Relations Teams and Aboriginal liaison officers, and the development of guidelines in a "Framework for Police Preparedness for Aboriginal Critical Incidents." 4 The guiding principles of these reforms are to build trust that would, in turn, enhance communication and improve the prospects for avoiding violent confrontation. Underlying these principles is an assumption that lack of direct communication - hindering police knowledge of potential protests and negotiation over

\footnotetext{
${ }^{4}$ In 2009, the OPP's Aboriginal Relations Teams and Major Events Liaison Teams were rebranded with a common name as Provincial Liaison Teams.
} 
their parameters - increases risk and thus the potential for violence. At the same time, the OPP formally adopted an intelligence-led policing framework, as well as made changes to public order policing such as by adopting a command and control structure and equipping Emergency Response Team members with less-than-lethal weapons - use of which would previously have required deployment of the Tactics and Rescue Unit (TRU) (OPP 2006a). Together these reforms emphasized improved decision-making based on the assumption that having more and better tactical intelligence would serve a preventative function and avert recourse to physical force, but also would contribute to developing future-oriented strategic intelligence.

The operationalization of these policing practices begins with the definition of "critical incident" itself, which implies a situation that is out of the ordinary, or, an exception to "normal" circumstances. According to the "Framework" (OPP 2006b, 2), a critical incident is

An incident where the source of conflict may stem from assertions associated with Aboriginal or treaty rights, e.g. colour of right, a demonstration in support of a land claim, a blockade of a transportation route, an occupation of local government buildings, municipal premises, provincial/federal premises or First Nations buildings.

There is an expanded definition in the OPP's “Aboriginal Initiatives: Building Respectful Relationships" (2006c, 49):

All incidents assessed to be high-risk on a First Nations' territory or involving an Aboriginal person, and where the potential for violence requires the activation of the OPP Integrated Response (Level 2 Incident Commander, ERT, TRU and Crisis Negotiators); or any incident where the source of conflict may stem from assertions associated with Aboriginal, inherent or treaty rights.

Through the two-part definition, the implication is that any incident involving an Indigenous person or relating to treaty or Aboriginal rights is considered "high-risk", which comes with the deployment of the highly coercive integrated response. ${ }^{5}$ As noted

\footnotetext{
${ }^{5}$ It should be noted that it was a member of the Tactics and Rescue Unit (TRU) that fatally shot Dudley George. According to the OPP's guidelines, the TRU is activated as part of the integrated response after a decision by the Incident Commander confirming the incident as "high risk" (OPP. 2006. OPP Emergency Response Services: A Comparison of 1995 to 2006. Accessed March 11, 2008.

http://www.attorneygeneral.jus.gov.on.ca/inquiries /ipperwash/policy_part/projects/pdf/Tab4_OPPEmergencyResponseServicesAComparisonof1995to2006.p df)
} 
by Commissioner Linden (2007) in his final report of the Ipperwash Inquiry, despite the vast majority of protests by Indigenous peoples having been characterized by little to no violence, there is a persistent perception and representation of such events as risky and threatening based on a perceived potential for violence. The "risk" posed by Indigenous resistance to the settler state provides the rationale for surveillance - and the production of intelligence - on Indigenous communities as a normalized colonial practice.

\section{Securing the Infrastructure of Settler-Colonialism: Surveillance and Security}

These official shifts in police forces' policy must be more broadly contextualized as an aspect of what Neocleous (2008) describes as an intensification of securitization since September 11, 2001, which challenges the perception that this is a novel or substantially different project from what was happening before. The intensification and expansion of the state security apparatus is directly linked to capital's expansionist logic. This is evident in the case of Indigenous struggles, which have long been cast as "problems" of "national security" because of the nature of the conflict. Self-determination struggles that hinge on the importance of land threaten settler state sovereignty. ${ }^{6}$ In 2007 , INAC noted - in a presentation to the RCMP - that the "vast majority of Hot Spots are related to lands and resources" and that "most are incited by development activities on traditional territories". ${ }^{7}$

With the on-going expansionist impulses of capitalism, the Canadian state has amplified its role in facilitating further "development" of land and resource extraction to maintain "competitiveness" in the global economy, imminently threatening Indigenous communities' land and self-determination. In this context, reclamations and blockades of "development" projects have been characterized as threats to (national) security because of their potential disruption of the critical infrastructure of the state, defined in both physical and economic terms. In its National Strategy for Critical Infrastructure, Public Safety Canada (PSC) defines "critical infrastructure" as "processes, systems, facilities, technologies, networks, assets and services essential to the health, safety, security or economic well-being of Canadians and the effective functioning of government" (Public Safety Canada 2009, 2). Critical infrastructure is further categorized into ten sectors: energy \& utilities, finance, food, transportation, government, information \& communication technology, health, water, safety (emergency preparedness) and manufacturing. Because critical infrastructure is defined as essential to the functioning of the state, its actual or potential disruption is defined as a national security threat. This

\footnotetext{
${ }^{6}$ On distinctions between self-determination and sovereignty, see e.g. Monture-Angus 1999; Alfred 2005; Corntassel 2008.

${ }^{7}$ INAC. 2007. Aboriginal Hot Spots and Public Safety [Presentation slides]. March 30. Obtained through ATI request to RCMP, no. GA-3951-3-00060/11.
} 
national security framing therefore legitimizes surveillance and other forms of intelligence-gathering as "preventative" and pre-emptive measures. In the current context of the dialectical intensification of conflict between capital's expansionist push and Indigenous resistance (see Alfred 2005; Gordon 2010), there has been an augmentation of intelligence networks, which include private sector "stakeholders" and government departments such as Indian and Northern Affairs Canada.

The importance of critical infrastructure to national security, and its implications for Indigenous resistance, is reflected by organizational changes to both the RCMP and CSIS. The establishment of the National Security Criminal Investigations (NSCI) Branch in the RCMP reflects the "securitization" of the police institution after September 11, 2001 to more prominently include national security within its jurisdiction. According to an NSCI orientation guide, the branch is "alone in attempting to prevent and/or investigate incidents where the state itself (and not necessarily any citizen in particular) is the direct target" (27). ${ }^{8}$ This includes "terrorist activities" as defined by the AntiTerrorism Act, and offences "arising out of a threat to the security of Canada" as defined by the CSIS Act (32). Within the NSCI, the Critical Infrastructure Criminal Intelligence (CICI) section currently focuses on the energy and utilities, transportation, and finance sectors, as well as cyber-security threats as they impact on these three sectors. Members of the CICI section actively cultivate relationships with private owners and operators in each of these sectors to encourage the exchange of information.

According to a 2007 RCMP briefing note, 85 percent of Canada's critical infrastructure is under private ownership and operation. ${ }^{9}$ It is not surprising therefore that the CICI section relies heavily on partnerships with third parties who are both "clients" (recipients of intelligence) and sources of information and intelligence. As part of the National Strategy for Critical Infrastructure, CSIS, RCMP and Natural Resources Canada (NRCan) have jointly hosted bi-annual meetings since 2005 during which energy companies are briefed on classified intelligence. The purpose of these meetings, according to NRCan, is to assist owners and operators "to plan and develop measures to protect their facilities." Yet, the subject matter of these briefings has included topics such as cyber-security, intellectual property rights and the 2010 Toronto G20 Summit. According to NRCan, the breadth of this subject matter is part of the "all-hazards" emergency management approach guiding the Strategy (Groves 2012). This reflects an increasingly formalized symbiosis between corporate entities and the Canadian state in the security project.

\footnotetext{
${ }^{8}$ RCMP. 2008. NSCI Orientation Guide. (Obtained by Tim Groves, Toronto Media Co-op, through ATI request to RCMP and released online). Accessed January 24, 2013. http://toronto.mediacoop.ca/blog/timgroves/14272.

${ }^{9}$ RCMP. 2007. Briefing note to Deputy Commissioner. June 4. Obtained through ATI request to RCMP, no. GA-3951-3-00060/11.
} 
Since 2004, the production of intelligence relating to national security threats has been centralized by the Integrated Threat Assessment Centre (ITAC) - renamed in June 2011 as the Integrated Terrorism Assessment Centre - which was established as part of Canada's National Security Policy. ITAC produces intelligence and threat assessments that are used to inform the coordinated response to national security threats by the Government of Canada. These products are developed through the exchange of intelligence with law enforcement and intelligence partners in Canada as well as a wide range of government departments and external domestic and international sources including counterparts in the US, Britain, Australia and New Zealand. ITAC's intelligence products are also disseminated to other levels of government, international partners and the private sector. While ITAC is a component of CSIS, it is staffed by representatives from its domestic partner agencies including the RCMP, Canada Border Services Agency, National Defence, and Transport Canada. Personnel from departments such as Health Canada, Environment Canada, and NRCan may be brought in when needed (ITAC 2012). INAC may also be seconded to ITAC, as was the case with the 2007 National Day of Action. In 2007, the Assembly of First Nations adopted a resolution calling for a National Day of Action on June 29 to raise awareness about issues affecting Indigenous communities. Although promoted as a "peaceful" event, several communities organized actions considered "militant". In preparations for the day, representatives from INAC were placed in ITAC to facilitate the exchange of information and to "enhance [its] analytic capacity" in producing threat assessments on "aboriginal protests". ${ }^{10}$

Historically, the contribution of INAC to the integrated production of national security intelligence stems from the department's colonial knowledge base of the social, political and economic dynamics, geographies and legal situations of the Indigenous communities under its administration. In 2006, INAC and Public Safety Canada (which includes RCMP and CSIS) developed an operational plan on "aboriginal occupations and protests" aimed at enhancing collaboration, communication and information-sharing between the two entities. ${ }^{11}$ The exchange of intelligence information among INAC and law enforcement and intelligence agencies is a long-standing practice that can be traced back to the relationship between Indian Affairs and the North West Mounted Police in the $19^{\text {th }}$ century (see Smith 2009). Surveillance, as Smith (2009) argues, was the main

\footnotetext{
${ }^{10}$ PSC. 2007. Federal Coordination Framework for AFN National Day of Action June 29 2007. May 8. Obtained through ATI request to PSC, no. 1336-A-2009-0052. In these ITAC threat assessments, the supremacy of securing "critical infrastructure" is clear: "the right of Canadians to engage in peaceful protest is a cornerstone of Canada's democratic society. ITAC is concerned only where there is a threat of politically-motivated violence, or where protests threaten the functioning of critical infrastructure" (Integrated Threat Assessment Centre (ITAC). 2007. Threat Assessment: Aboriginal Protests Summer 2007. May 11. Obtained through ATI request to CSIS, no. 117-2008-123).

${ }^{11}$ INAC. 2007. Aboriginal Hot Spots and Public Safety [Presentation slides]. March 30. Obtained through ATI request to RCMP, no. GA-3951-3-00060/11.
} 
modality of colonial power in this period, backed by the omnipresent threat of coercive police or military intervention. Since the early 2000s, INAC has been enhancing and systematizing its own internal production of intelligence. While these contemporary practices adopt new means, formats and configurations, they are continuous with Indian Affairs' historical surveillance practices as a key mechanism of settler-colonial pacification.

As part of the Canadian government's implementation of the Emergency Preparedness Act in 1988, INAC established an Emergency Management Assistance Program (EMAP). Initially, the EMAP was limited to coordinating assistance for fire suppression services and search and recovery operations for reserve communities. The scope of "emergencies" was expanded in 2004 to include a wider range of activities relating to health and safety, as well as infrastructure and housing. In 2007, the federal government introduced the Emergency Management Act, which set out four pillars of emergency management reflecting a preventive "all-hazards" approach: mitigation, preparedness, response and recovery.

Significantly, the Act also broadened the definition of emergency to include "civil disobedience". ${ }^{12}$ A 2007 INAC review of its EMAP recommended the establishment of a dedicated section to administer the program and the inclusion of "civil disobedience" within its formal mandate. ${ }^{13}$ These recommendations were implemented in 2008 as INAC established the Emergency and Issues Management Directorate (EIMD) to manage the EMAP in line with the four pillars. "Civil unrest" was gradually incorporated into the formal purview of the EIMD as a form of "human induced emergency" - a category that also includes "terrorist acts". According to a 2010 evaluation of the EMAP, the rationale for monitoring civil unrest in Indigenous communities stems from the fact that "the outcomes of these events have a direct impact on First Nations and, by extension, on the Department". This includes civil unrest that occurs off of reserves, which is outside INAC's authority (INAC 2010, 18, 32). All potential and occurring "unrest" and events "are closely monitored and, in cases of escalation, INAC's regional offices are in a position to provide assistance to first responders in order to better understand issues that may have triggered these protests and to mitigate risks to individuals and property" (INAC 2010, 39). Of course, in the case of protests, "first responders" would be the police forces of jurisdiction.

INAC's surveillance - or to use its own terminology, "monitoring" - of Indigenous communities is coordinated by the national headquarters' Emergency

\footnotetext{
${ }^{12}$ Under the Emergency Management Act, all federal departments are expected to implement measures consistent with this all-hazards framework.

${ }^{13}$ Holman, Brad. 2007. Final Report: Formative Evaluation - Indian and Northern Affairs Emergency Management Assistance Program. July 31. Ottawa: Indian and Northern Affairs Canada. Obtained through ATI request to INAC, no. A-2011-01156.
} 
Management Operations Centre (EMOC). On-the-ground monitoring and operations are carried out by each of INAC's ten Regional Emergency Management Operations Centres, ${ }^{14}$ which report events and activities occurring within the region to the national EMOC. The regional offices are responsible for developing and maintaining direct relationships with reserve communities, and a range of other "partners" including provincial and territorial emergency management offices, non-governmental organizations, private sector representatives, Indigenous peoples' organizations and municipal governments (Aboriginal Affairs and Northern Development Canada 2011). Monitoring is not limited to INAC's own activities but draws on information from the Department of Fisheries and Oceans, Northern Resources Canada, federal negotiation teams, media and police intelligence. ${ }^{15}$ Both the regional and national EMOCs produce a variety of "situational awareness products" that are shared with INAC senior management, intelligence agencies, law enforcement and other first responders (such as fire services), and other agencies on a continuous basis. The products include situation reports and notifications about specific events, which are produced and disseminated as events or "issues" emerge. Based on an analysis of these records obtained through access to information requests, it is common for two or three notifications to be issued for a single event. Weekly summary reports are produced that provide a roundup of issues coming onto the EIMD's radar for that week. Weekend summary reports are notices of events to watch for, providing contact information for an on-duty EIMD officer to report to. The reporting system had been referred to informally as the "hot spots reporting system", particularly in reference to protest "hot spots". Based on an analysis of summaries produced between 2007 and 2011 by HQ and Ontario Region, the most common types of issues appearing in these summaries are forest fires, flooding and "civil unrest". ${ }^{16}$ Since 2009 the EIMD appears to be devoting more resources to monitoring and analysis of "civil unrest" with an interest in identifying trends. This is reflected in the production of incident reports beginning in 2009-10. According to the 2009-10 report, 109 of 217 reported "incidents" were protests; in 2010-11, 91 of 251 incidents were protests. ${ }^{17}$

It is of significance to note that the Emergency Management Act giving rise to the EIMD and its focus on "civil unrest" received assent on June 22, 2007 - seven days before the planned National Day of Action. On March 30, INAC representatives made a

\footnotetext{
${ }^{14}$ Each province and territory has its own regional office except for the Atlantic provinces, which are served by one Atlantic regional office.

${ }^{15}$ INAC. 2007. Aboriginal Hot Spots and Public Safety [Presentation slides]. March 30. Obtained through ATI request to RCMP, no. GA-3951-3-00060/11.

16 These reports were obtained through ATI requests A-2010-00831, A-2010-02632, A-2011-02004, A-20112003, A-2011-01157, A-2012-0033, and A-2012-0032.

${ }^{17}$ INAC. 2010. Incident Report 2009-2010: Emergency and Issue Management at INAC. August. Obtained through ATI request to INAC, no. A-2012-00257.
} 
presentation to the RCMP, highlighting its "hot spot reporting system" as a key source of information about protest risks. According to the presentation there is a "synergy" between INAC's system and those of CSIS, ITAC, RCMP and the Government Operations Centre. ${ }^{18}$ In 2009, INAC developed a Police Interchange Program through which a police officer is seconded to the EIMD office to provide advice and support from a law enforcement perspective. The program is intended to enhance collaboration between INAC and Canadian law enforcement organizations. This interfacing of INAC operations and police-security institutions is directly connected with the state's prioritization of securing territory and resources - "critical infrastructure" - as issues of national security (see Diabo and Pasternak 2011).

INAC's "monitoring" of protests is intertwined with its responsibility for claims and negotiations relating to Indigenous land and treaty rights. The conflict of interest in INAC's double-role as both negotiator and defendant to Indigenous challenges is compounded by its direct participation in the policing of protests that often arise out of frustrations with the political-legal processes of the state and with INAC itself. In the context of the 2007 NDA, INAC's involvement was not limited to contributing information to the intelligence gathering of law enforcement and intelligence partners; the department's bureaucratic and political power - deriving from its administration of land claims, policy and funding arrangements - was also deployed as a key strategy in the state's pacification efforts.

Paralleling the negotiation-based approach to public order policing discussed above, INAC representatives (including the minister of Indian Affairs) played a direct role in "negotiations" with First Nations leaders aimed at preventing potentially disruptive direct actions. Email exchanges within PSC and the Department of National Defence (DND) discuss INAC's active role in attempting to convince leaders to "stand down their plans" for the NDA. ${ }^{19}$ A priority in the state's overall policing strategy was to contain "hot spots". One "hot spot" of particular concern to INAC, police and intelligence organizations was the on-going reclamation by the Haudenosaunee of Six Nations of Grand River. In February of 2006, members of the community "occupied" land near Caledonia, Ontario, which halted construction of the Douglas Creek Estates housing development by Henco Industries. A pre-dawn raid on the site by the Ontario Provincial Police on April 20 had escalated tensions and fuelled several disruptive solidarity actions. $^{20}$ The situation at Caledonia was identified by PSC, RCMP, CSIS, and INAC as a

\footnotetext{
${ }^{18}$ The Government Operations Centre is PSC's emergency operations centre into which all other departmental emergency management systems are connected.

${ }^{19}$ DND, email, May 31 2007. Obtained through informal ATI request to DND, no. A-2007-00590.

${ }^{20}$ For more on the reclamation, see Laura DeVries. 2012. Conflict in Caledonia: Aboriginal Land Rights and the Rule of Law. Vancouver: UBC Press. For an analysis of the policing operation, see Tia Dafnos. 2012. Beyond the Blue Line: Researching the policing of aboriginal activism using access to information, in
} 
"militant" one that had the potential to further galvanize other Indigenous communities; as such, there was concern to avoid overt confrontation. ${ }^{21}$ The Six Nations of Grand River have a number of outstanding land claims with INAC, including the one encompassing the reclaimed land that was trickling through the system as Henco began construction. One month before the National Day of Action, a secret DND email revealed that INAC had "made a significant offer related to Caledonia and plans to make some broader policy announcements in the coming weeks as preventative measures. Everything will be timed carefully". ${ }^{22}$ In its contribution to the coordinated government strategy in policing the NDA, INAC offered a $\$ 125$ million settlement in four of the other Haudenosaunee claims, contingent on ending the reclamation and providing assurances that future reclamations would not occur (Daly 2007). The offer was rejected and the reclamation continues today while the land claim remains in the institutional system.

\section{Conclusion}

These fragments or snapshots of contemporary pacification in Canada show how the ideological binaries of liberal-legalism and security logic fall apart when we adopt an anti-security approach that understands policing as pacification. By focusing specifically on the pacification of Indigenous self-determination, we can see how a wide range of policing practices work in and through each other - continuous and simultaneously - to contain resistance while securing intertwined interests of settler state sovereignty and capitalist accumulation. The fluidity and inter-connectedness of these strategies defy categorization as being either/or soft-hard, low-high, or public-private. Re-appropriation of the term pacification is, as Neocleous (2011) argues, a political move, and one that is imperative in countering the denial or erasure of the reality of settler-colonialism in dominant discourses. The association of pacification with inter-nation warfare, applied as a lens through which to understand policing practices and institutions of the Canadian state, keeps the colonial and imperial dynamics of the state at the fore. This is perhaps especially vital as the acceleration of neoliberalism continues to intensify struggles. Instead of a decline of state violence as implied by liberal legalism, Gordon (2010) argues that there has been an increase of coercion directed at Indigenous resistance, enacted

Brokering Access: Power, Politics and Freedom of Information Processes in Canada, edited by Mike Larsen and Kevin Walby. 209-233. Vancouver: UBC Press.

${ }^{21}$ PSC. 2007. Federal Coordination Framework for AFN National Day of Action June 29 2007. May 8. Obtained through ATI request to PSC, no. 1336-A-2009-0052.

${ }^{22}$ DND, email, May 31 2007. Obtained through informal ATI request to DND, no. A-2007-00590. The reference to policy changes likely refers to proposals for a Specific Claims Tribunal, and the eventual release of an action plan Specific Claims: Justice at Last, which outlined four pillars of impartiality, transparency, faster processing of claims and improved access to mediation. These measures received assent in 2008 (see Pasternak, Collis and Dafnos, 2013). 
through both lawfare and more direct coercive, intrusive policing. This intensification of pacification also extends to poor and working class people, who are disproportionately people of colour, women and migrants, targeted by increasingly punitive social policies and the expanding prison-industrial complex.

The emergence of the Idle No More movement, and associated actions, at the end of 2012 that has continued into 2013 reflects a culmination of frustration, distinguished by its duration, diversity of tactics, and geographical scope. The movement has included a significant number of disruptions of railways, highways and border crossings. While front-line police forces have been most visible in responding to protest activities, the national security, political, legal and administrative apparatuses are very much active in this exercise-in partnership with the private sector. The potential scale of coordinated resistance by Indigenous peoples and the escalation of direct actions disrupting critical infrastructure, pose a significant threat to Canada's political economy, which creates the conditions for further exposing the settler-colonial politics of security-liberal ideology through the state's response.

\section{References}

Aboriginal Affairs and Northern Development Canada. 2011. National Emergency Response Plan. Ottawa: Public Works and Government Services Canada.

Alfred, Taiaiake. 2005. Wasáse: Indigenous Pathways of Action and Freedom. Peterborough: Broadview Press.

- - - and Jeff Corntassel. 2005. "Being Indigenous: Resurgences Against Contemporary Colonialism.” Government and Opposition 40(4): 597-614.

Borrows, John. 2006. "Crown and Aboriginal Occupations of Land: A History \& Comparison." Paper prepared for the Ipperwash Inquiry. Accessed December 13, 2012.

http://www.attorneygeneral.jus.gov.on.ca/inquiries/ipperwash/policy_part/researc h/pdf/History_of_Occupations_Borrows.pdf

Brown, Wendy. 1995. States of Injury: Power and Freedom in Late Modernity. New Jersey: Princeton University Press.

CBC News. 2013. "PM Meets with Chiefs Amid First Nations Boycotts and Protests." CBC News. January 11. Accessed January $11 \quad 2013$. 
http://www.cbc.ca/news/politics/story/2013/01/11/pol-first-nations-spence-pmgg-talks-friday.html

Comaroff, Jean and John Comaroff. 2007. "Law and Disorder in the Postcolony." Social Anthropology 15(2): 133-152.

Corntassel, Jeff. 2008. "Toward Sustainable Self-Determination: Rethinking the Contemporary Indigenous-Rights Discourse." Alternatives 33: 105-132.

Coulthard, Glen. S. 2007. "Subjects of Empire: Indigenous Peoples and the 'Politics of Recognition' in Canada." Contemporary Political Theory 6(4): 437-460.

Daly, Rita. 2007. "Caledonia Offer: \$125 Million: Ottawa Seeks an End to 4 Land Claim Disputes, but Native Chief Calls it a 'Starting Point.” Toronto Star, May 31, A01.

Dhamoon, Rita and Yasmeen Abu-Laban. 2009. "Dangerous (Internal) Foreigners and Nation-building: The Case of Canada.” International Political Science Review 30 (2): 163-183.

Diabo, Russell. 2012. "Harper Launches Major First Nations Termination Plan: As Negotiating Tables Legitimize Canada's Colonialism.” First Nations Strategic Bulletin 10(7-10). Accessed January 4 2013. http://intercontinentalcry.org/wpcontent/uploads/2012/11/FNSB-July-Oct-12.pdf

_-_, and Shiri Pasternak. 2011. "Canada has had First Nations Under Surveillance: Harper Government has Prepared for First Nations 'Unrest'." First Nations Strategic Bulletin 9(1-5). Accessed December 13, 2012. http://www.scribd.com/doc/57561401/First-Nations-Strategic-Bulletin-Jan-May2011

Ford, Richard. 2002. "Beyond Difference: A Reluctant Critique of Legal Identity Politics." In Left Legalism/Left Critique, edited by Wendy Brown and Janet Halley. 38-79. London: Duke University Press.

Foucault, Michel. 2007. Security, Territory, Population: Lectures at the College de France 1977-1978. New York: Picador.

Goodale, Mark. 2005. "Empires of Law: Discipline and Resistance within the Transnational System.” Social and Legal Studies 14(4): 553-583. 
Gordon, Todd. 2006. Cops, Crime and Capitalism: The Law and Order Agenda in Canada. Halifax: Fernwood.

———. 2010. Imperialist Canada. Winnipeg: Arbeiter Ring Publishing.

Groves, Tim. 2012. "Canada's Spy Groups Divulge Secret Intelligence to Energy Companies." The Dominion. October 10. Accessed October 12, 2012. http://www.dominionpaper.ca/articles/4640.

Henderson, James (Sákéj) Youngblood. 2002. "Postcolonial Indigenous-Legal Consciousness.” Indigenous Law Journal 1: 1-56.

INAC. 2010. Final Report - Evaluation of the Emergency Management Assistance Program. Accessed March 12, 2012. http://www.aadncaandc.gc.ca/eng/1100100011392/1100100011397.

ITAC. 2012. ITAC Agenda 2012. Accessed August 2, 2012. http://www.itacciet.gc.ca/pblctns/gnd/FINAL_ITAC_Agenda_2012-eng.pdf

King, Mike and David Waddington. 2006. "The Policing of Transnational Protest in Canada." In The Policing of Transnational Protest, edited by Donatella Della Porta, Abbey Peterson, and Herbert Reiter, 75-96. Aldershot: Ashgate Publishing.

LaRocque, Emma. 2010. When the Other is Me: Native Resistance Discourse, 1850-1990. Winnipeg: University of Manitoba Press.

Linden, Sidney. 2007. Ipperwash Inquiry Report, Volume 2. Accessed May 11, 2009. http://www.attorneygeneral.jus.gov.on.ca/inquiries/ipperwash/report/vol_2/pdf/E _Vol_2_CH02.pdf

McPhail, Clark and John McCarthy. 2005. "Protest Mobilization, Protest Repression, and their Interaction." In Repression and Mobilization, edited by Christian Davenport, Hank Johnston and Carol Muller, 3-32. Minneapolis: University of Minnesota Press.

- - D David Schweingruber and John McCarthy. 1998. "Policing Protest in the United States: 1960-1995." In Policing Protests: The Control of Mass Demonstrations in 
Western Democracies, edited by Donatella Della Porta and Herbert Reiter, 49-69. Minneapolis: University of Minnesota Press.

Maaka, Roger and Augie Fleras. 2005. The Politics of Indigeneity: Challenging the State in Canada and Aotearoa New Zealand. Dunedin, New Zealand: University of Otago Press.

Manuel, George and Michael Posluns. 1974. The Fourth World: An Indian Reality. New York: Collier Macmillan Canada.

Monture-Angus, Patricia. 1999. Journeying Forward: Dreaming First Nations Independence. Halifax: Fernwood.

Neocleous, Mark. 2000. The Fabrication of Social Order: A Critical Theory of Police Power. London: Pluto Press.

———. 2008. Critique of Security. Montreal: McGill-Queen's University Press.

_—_. 2010. “War as Peace, Peace as Pacification.” Radical Philosophy 159:8-17.

-_- 2011. "Security as Pacification." In Anti-Security, edited by Mark Neocleous and George S. Rigakos, 23-56. Ottawa: Red Quill Books.

- - , and George S. Rigakos. 2011. “Anti-Security: A Declaration.” In Anti-Security, 1521. Ottawa: Red Quill Books.

OPP 2006a. OPP Public Order Units: A Comparison of 1995 to 2006. Accessed March 11, 2008.

http://www.attorneygeneral.jus.gov.on.ca/inquiries/ipperwash/policy_part/project s/pdf/Tab5_OPPPublicOrderUnitsAComparisonof1995to2006.pdf

- - . 2006b. A Framework for Police Preparedness for Aboriginal Critical Incidents Accessed December 15, 2009. http://www.attorneygeneral.jus.gov.on.ca/inquiries/ipperwash/policy_part/project s/pdf/OPP_Appendix_E_Framework_for_Police_Preparedness.pdf

-——. 2006c. Aboriginal Initiatives: Building Respectful Relationships. Accessed March $11,2008$. 
http://www.attorneygeneral.jus.gov.on.ca/inquiries/ipperwash/policy_part/project s/pdf/Tab2_OPPAboriginalInitiativesBuildingRespectfulRelationships.pdf

Pasternak, Shiri, Sue Collis and Tia Dafnos. 2013. "Criminalization at Tyendinaga: Securing Canada's Colonial Property Regime through Specific Land Claims.” Canadian Journal of Law and Society. doi: 10.1017/cls.2013.4.

Public Safety Canada. 2009. National Strategy for Critical Infrastructure. Accessed April 14, 2013. http://www.publicsafety.gc.ca/prg/ns/ci/_fl/ntnl-eng.pdf

Razack, Sherene. 2002. "Gendered Racial Violence and Spatialized Justice: The Murder of Pamela George." In Race, Space and the Law: Unmapping a White Settler Society, edited by S. Razack, 121-56. Toronto: Between the Lines.

Rigakos, George S. 2011. “To Extend the Scope of Productive Labour': Pacification as a Police Project." In Anti-Security, edited by Mark Neocleous and George S. Rigakos, 57-84. Ottawa: Red Quill Books.

-_-, John McMullan, Joshua Johnson and Gulden Ozcan, eds. 2009. "Introduction." In A General Police System: Political Economy and Security in the Age of Enlightenment, 1-32. Ottawa: Red Quill Books.

Samuelson, Les and Patricia Monture. 2008. "Aboriginal People and Social Control: The State, Law, and 'Policing'." In Marginality and Condemnation: An Introduction to Criminology, 2nd ed., edited by Carolyn Brooks and Bernard Schissel, 200-219. Halifax: Fernwood.

Simpson, Leanne, ed. 2008. Lighting the Eighth Fire: The Liberation, Resurgence and Protection of Indigenous Nations. Winnipeg: Arbeiter Ring.

Smith, Kevin. 2009. Liberalism, Surveillance, and Resistance: Indigenous Communities in Western Canada, 1877-1927. Edmonton: AU Press.

Waddington, P.A.J. 1998. "Controlling Protest in Contemporary Historical and Comparative Perspective." In Policing Protests: The Control of Mass Demonstrations in Western Democracies, edited by in Donatella Della Porta and Herbert Reiter, 117-142, Minneapolis: University of Minnesota Press. 
Wolfe, Patrick. 2006. "Settler Colonialism and the Elimination of the Native." Journal of Genocide Research 8(4): 387-409.

Veracini, Lorenzo. 2010. Settler Colonialism: A Theoretical Overview. Basingstoke: Palgrave Macmillan. 